\title{
Synthesis and P1' SAR Exploration of Potent Macrocyclic Tissue Factor-Factor VIIa Inhibitors
}

\author{
Vladimir (Uladzimir) Ladziata, ${ }^{*}$ Peter W. Glunz, Yan Zou, ${ }^{\dagger}$ Xiaojun Zhang, Wen Jiang, Swanee Jacutin- \\ Porte, Daniel L. Cheney, Anzhi Wei, Joseph M. Luettgen, Timothy M. Harper, Pancras C. Wong, Dietmar \\ Seiffert, Ruth R. Wexler, E. Scott Priestley
}

Bristol-Myers Squibb Research \& Development, Princeton, New Jersey 08543, United States

\section{ARTICLE INFO}

\section{ABSTRACT}

Article history:

Received

Revised

Accepted

Available online

Keywords:

Thrombosis

Anticoagulant

Factor VIIa-TF inhibitor

Macrocycle

\begin{abstract}
Selective tissue factor-factor VIIa complex (TF-FVIIa) inhibitors are viewed as promising compounds for treating thrombotic disease. In this contribution, we describe multifaceted exploratory SAR studies of S1'-binding moieties within a macrocyclic chemotype aimed at replacing cyclopropyl sulfone P1' group. Over the course of the optimization efforts, the 1-(1Htetrazol-5-yl)cyclopropane $\mathrm{P}^{\prime}$ ' substituent emerged as an improved alternative, offering increased metabolic stability and lower clearance, while maintaining excellent potency and selectivity.
\end{abstract}

2016 Elsevier Ltd. All rights reserved.
Thrombosis-related disorders, such as myocardial infarction (MI), thromboembolic stroke, deep vein thrombosis (DVT) and pulmonary embolism (PE), are the leading cause of death in the industrialized world. ${ }^{1}$ Traditional therapies, which include low molecular weight heparin (LMWH) and warfarin, suffer from a number of drawbacks which limit their utility for long-term use. Namely, LMWH is administered only via parenteral route, while use of warfarin is complicated by a slow onset of action, food effects, and requires close monitoring due to a substantial bleeding risk. ${ }^{2}$ Therefore, in the past several decades much research has focused on discovery and development of thrombin and factor $\mathrm{Xa}$ small molecule inhibitors with improved pharmacokinetic and pharmacodynamic parameters. ${ }^{3}$ Among approved novel oral anticoagulants (NOACs), which target these two specific blood coagulation cascade enzymes, are the thrombin inhibitor dabigatran etexilate (Pradaxa $\left.{ }^{\circledR}\right),{ }^{4 a-d}$ and the factor Xa inhibitors rivaroxaban $\left(\right.$ Xarelto $\left.^{\circledR}\right)$, ${ }^{4 \mathrm{e}-\mathrm{h}}$ apixaban $\left(\text { Eliquis }{ }^{\circledR}\right)^{4 \mathrm{i}-\mathrm{k}}$ and edoxaban $\left(\right.$ Savaysa $\left.{ }^{\circledR}\right){ }^{41, \mathrm{~m}}$ The introduction of these novel antithrombotics into the clinical practice enables replacement of the traditional therapies in many patients. ${ }^{5}$

Given the fact that the tissue factor-factor VIIa complex (TFFVIIa) is situated at a critical initiation point of the coagulation cascade, factor VIIa inhibitors are regarded as a pharmacologically attractive class of anticoagulants, and much pharmaceutical research efforts over the past two decades have been devoted to finding orally bioavailable TF-FVIIa small molecule inhibitors. ${ }^{6}$ The TF-VIIa complex plays a key role in initiation of the extrinsic coagulation pathway: circulating zymogen FVII interacts with membrane-anchored TF, which is exposed upon pathophysiological vascular injury or atherosclerotic plaque rupture, thereby forming the proteolytically active TF-FVIIa complex. ${ }^{7 \mathrm{a}}$ The initial step is then amplified/propagated via activation of factors IX and X, leading to direct generation of additional FVIIa in the former case, and thrombin formation in the latter; thrombin in turn cleaves fibrinogen to fibrin and mobilizes platelets through proteaseactivated receptors, which ultimately results in stable clot formation. ${ }^{7 \mathrm{~b}}$ Moreover, FVIIa target validation was accomplished in numerous in vivo models utilizing biological agents, ${ }^{8 \mathrm{a}-\mathrm{c}}$ as well as multiple small molecule chemotypes, ${ }^{8 d-1}$ where effective anticoagulation coupled with low risk of bleeding was consistently observed. Furthermore, apart from their apparent utility as antithrombotics, TF-FVIIa inhibitors may also possess clinical potential in tumor metastasis via inhibition of proteaseactivated receptor 2 (PAR2) signaling, ${ }^{9}$ and in inflammation. ${ }^{10}$

\footnotetext{
* Corresponding author. Tel.: +1-609-466-5055; fax: +1-609-818-3550; e-mail: vladimir.ladziata@bms.com.

${ }^{\dagger}$ Co-author deceased. Date of death: 03/21/2014.
} 

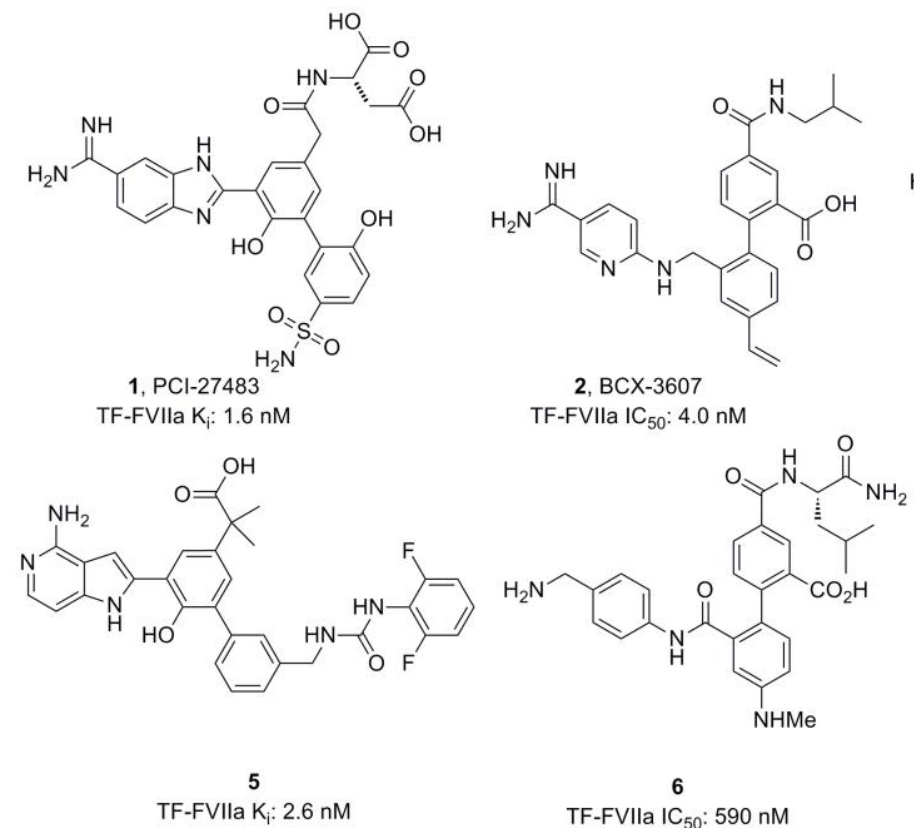

TF-FVIIa IC 5 : $: 590 \mathrm{nM}$

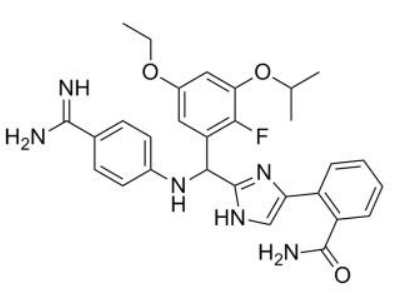

3 (racemic)

TF-FVIla $\mathrm{K}_{\mathrm{i}}: 1.7 \mathrm{nM}$

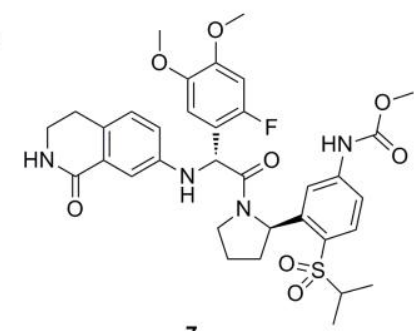

TF-FVIla $K_{\mathrm{i}}: 130 \mathrm{nM}$

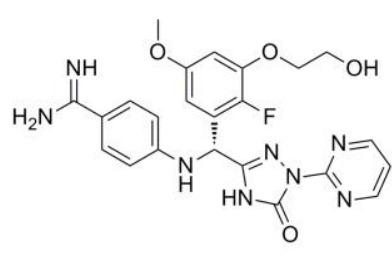

4, ER-410660 TF-FVIla $\mathrm{K}_{\mathrm{i}}: 4.9 \mathrm{nM}$

Figure 1. Selected structures of disclosed TF-FVIIa inhibitors 1-8.

A number of diverse series of small molecule TF-FVIIa inhibitors have been reported to date. ${ }^{11}$ Based on the interaction with the polar primary specificity pocket, the reported FVIIa inhibitors could be nominally divided into two categories. The first group is comprised of compounds bearing strongly basic benzamidine P1 moieties, ${ }^{12 a}$ which are characterized by high TFFVIIa inhibitory potency, but exhibit low permeability and poor oral absorbance. Conversely, the second group includes compounds with less basic non-benzamidine P1 groups, which ordinarily possess improved permeability, albeit at the expense of TF-FVIIa binding affinity. Some representative examples of benzamidine $(\mathbf{1 - 4})^{12 \mathrm{~b}-\mathrm{f}}$ and non-benzamidine $(\mathbf{5 - 8})^{12 \mathrm{~g}-\mathrm{f}}$ small molecule TF-FVIIa inhibitors are shown in Figure 1. Very recently our research team reported novel 16-membered macrocyclic FVIIa inhibitors, bearing an aminoisoquinoline P1 group. ${ }^{12 \mathrm{j}}$ Macrocycle $\mathbf{8}$ is a potent FVIIa inhibitor with excellent selectivity ( $>500$ fold) against primary serine protease antitargets FIXa, FXa, thrombin and trypsin, and excellent FVII deficient prothrombin time ${ }^{13} \mathrm{EC}_{2 \mathrm{x}}$ of $1.2 \mu \mathrm{M}$. Furthermore, the macrocycle provided a rigid scaffold allowing for direct optimization of $\mathrm{P} 1, \mathrm{P} 2$ and $\mathrm{P} 1$ ' groups.

Considering TF-FVIIa inhibition is likely to provide an apparent therapeutic benefit for various thrombosis-related diseases, our research laboratories aimed at developing potent and selective TF-FVIIa inhibitors with improved ADME properties. Building on the initial success of the macrocyclization strategy applied to FVIIa inhibitors, Glunz et al. further enhanced this approach by utilizing rational structure-guided atropisomer control via incorporation of a P2 benzylic methyl group, and thereby locking macrocyclic scaffold in the bioactive conformation. ${ }^{14}$ From the resulting conformationally stable macrocyclic template, Zhang et al. subsequently undertook detailed structure-activity relationship (SAR) studies in the P1 and $\mathrm{P} 1$ ' regions of the macrocyclic core. ${ }^{15}$ After surveying a number of $\mathrm{P} 1$ ' moieties, cyclopropyl sulfone was identified as an optimal group. Namely, compound $\mathbf{9}$ demonstrated outstanding TF-FVIIa binding affinity and anti-clotting activity $\left(\mathrm{K}_{\mathrm{i}}=0.16\right.$ $\left.\mathrm{nM}, \mathrm{EC}_{2 \mathrm{x}}=1.1 \mu \mathrm{M}\right)$ coupled with an excellent selectivity profile (Figure 2).
Despite having good metabolic stability (dog liver microsomes ${ }^{16} \mathrm{t}_{1 / 2}=106 \mathrm{~min}$ ), inhibitor 9 showed elevated dog clearance at $29 \mathrm{~mL} / \mathrm{min} / \mathrm{kg}$, indicating rapid elimination of the compound. In addition, FVIIa inhibitor 9 demonstrated very low dog oral exposure, presumably due to limited permeability. ${ }^{15}$ Indeed, passive Caco-2 permeability ${ }^{17}$ for macrocycle 9 measured lower at $47 \mathrm{~nm} / \mathrm{s}$.

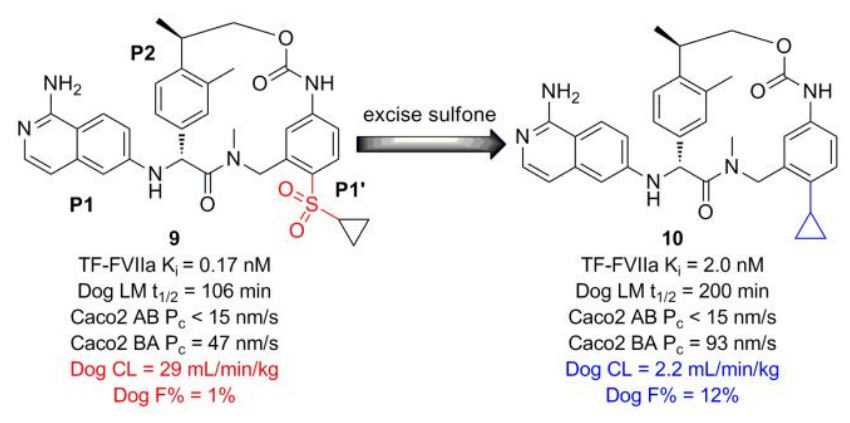

Figure 2. Comparison of sulfone P1' 9 and des-sulfone P1' 10.

We envisioned that polar sulfone functionality in inhibitor 9 could be partially responsible for the poor dog pharmacokinetic (PK) profile. To that end, we synthesized analog 10, where the $-\mathrm{SO}_{2}$ - fragment is excised, and the cyclopropyl group is directly attached to the macrocyclic scaffold (Figure 2). We were delighted to learn that upon p.o. and i.v. administration of compound $\mathbf{1 0}$ in dogs oral bioavailability and clearance were much improved. It should be noted that whereas analog 10, in comparison to sulfone counterpart 9 , possessed improved passive Caco-2 permeability and maintained good metabolic stability, TF-FVIIa $K_{i}$ was reduced ( 12 fold), along with selectivity against a number of serine proteases (data not shown). Therefore, we decided to modify macrocycle $\mathbf{1 0}$ at the cyclopropyl P1' region in order to improve TF-FVIIa inhibitory activity and selectivity, while at the same time maintaining the ADME profile. Equipped with structural information for the S1' binding pocket we obtained previously, ${ }^{12 \mathrm{e}, 12 \mathrm{j}, 18}$ we aimed at expanding the cyclopropyl ring in order to enhance hydrophobic interaction with the Cys42-Cys58 disulfide bridge, as well as engaging 
Lys60A side chain via incorporating acidic groups as shown in Figure 3. Since we previously demonstrated that the 4fluoroaminoisoquinoline P1 group imparts better permeability due to reduced basicity, ${ }^{15}$ we decided to use 4fluoroaminoisoquinoline bearing macrocyclic scaffolds for the P1' SAR examination described below.

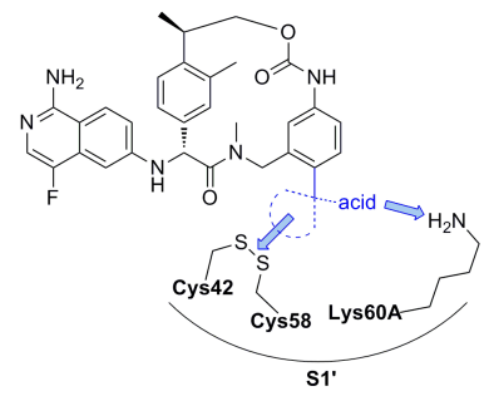

Figure 3. Design strategy for novel macrocyclic FVIIla inhibitors.

Synthesis of cyclopropyl $\mathrm{P}^{\prime}$ precursor $\mathbf{1 8}$ is depicted in Scheme 1. Commercially available 2-bromobenzaldehyde $\mathbf{1 1}$ was nitrated, and the obtained nitrobenzaldehyde $\mathbf{1 2}$ was treated sequentially with $\mathrm{MeNH}_{2}$ and $\mathrm{NaBH}_{4}$ in $\mathrm{MeOH}$ to afford $\mathrm{N}$ methyl benzylamine 13 in good yield. Compound 13 was subsequently converted to the corresponding Boc- and Cbzprotected derivatives 14 and 15 under standard conditions. Synthesis of 4-cyclopropylaniline $\mathbf{1 8}$ was achieved in three steps starting with Boc-protected bromobenzylamine 14 via sequential Pd-catalyzed cyclopropanation, ${ }^{19}$ followed by $\mathrm{Zn}$-mediated reduction of the nitro group, and Boc removal. It should be noted that reduction of $\mathbf{1 6}$ to $\mathbf{1 7}$ under hydrogenative conditions $\left(\mathrm{H}_{2}(1\right.$ atm), Pd-C) resulted in a partial cyclopropyl ring opening giving rise to the respective $n$-propyl contaminant.
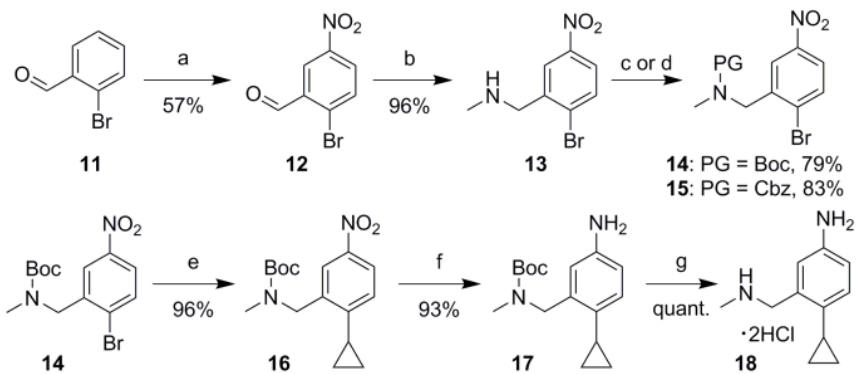

Scheme 1. Synthesis of 1-cyclopropyl P1' building block 18. Reagents and conditions: (a) $\mathrm{HNO}_{3}, \mathrm{H}_{2} \mathrm{SO}_{4}, 0^{\circ} \mathrm{C}, 2 \mathrm{~h}$; (b) i. $\mathrm{MeNH}_{2}, \mathrm{MeOH}$, rt, $1 \mathrm{~h}$; ii. $\mathrm{NaBH}_{4}, \mathrm{MeOH}, 0^{\circ} \mathrm{C}$ to rt, $5 \mathrm{~h}$; (c) $\mathrm{Boc}_{2} \mathrm{O}$, TEA, THF, $40{ }^{\circ} \mathrm{C}, 2 \mathrm{~h}$; (d) Cbz-Cl, TEA, THF, $0{ }^{\circ} \mathrm{C}$ to rt, $3 \mathrm{~h}$; (e) $c \mathrm{PrB}(\mathrm{OH})_{2}, \mathrm{Pd}(\mathrm{OAc})_{2}, \mathrm{PCy}_{3}, \mathrm{~K}_{3} \mathrm{PO}_{4}$, PhMe$\mathrm{H}_{2} \mathrm{O}, 100{ }^{\circ} \mathrm{C}, 12 \mathrm{~h}$; (f) $\mathrm{Zn}, \mathrm{NH}_{4} \mathrm{Cl}, \mathrm{MeOH}-\mathrm{THF}$, rt then $40{ }^{\circ} \mathrm{C}, 3 \mathrm{~h}$; (g) $\mathrm{HCl}$, dioxane, $30 \mathrm{~min}$.

In order to obtain advanced intermediates to explore the Lys60A binding vector as shown in Figure 3, we carried out a six step sequence starting with Cbz-protected bromoarene 15. As shown in Scheme 2, CuI/(S)-Pro-catalyzed C-arylation of malonates, disclosed by $\mathrm{Ma}$ and co-workers, ${ }^{20}$ afforded corresponding malonate 20 and cyanoacetate 21 in excellent yields. Intermediates $\mathbf{2 0}$ and $\mathbf{2 1}$ were decarboxylated in a facile manner under Krapcho conditions, ${ }^{21}$ and the subsequent succession of reduction and protecting group swap resulted in diBoc protected intermediates $\mathbf{2 4}$ and $\mathbf{2 5}$. Ensuing condensation with paraformaldehyde under basic conditions provided styrenes
26 and 27. Gratifyingly, the double bonds of $\mathbf{2 6}$ and 27 were efficiently cyclopropanated under Corey-Chaykovsky conditions, ${ }^{22}$ and subsequent Boc removal provided building blocks 30 and 31 (Scheme 2).

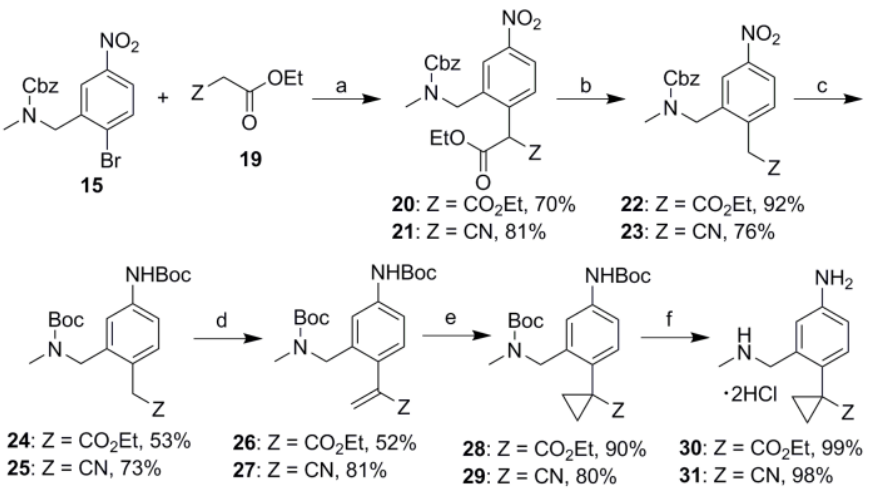

Scheme 2. Synthesis of substituted cyclopropyl P1' building blocks 30 and 31. Reagents and conditions: (a) $\mathrm{CuI}$ (0.2 equiv.), ( $S$ )-Proline (0.4 equiv.), $\mathrm{Cs}_{2} \mathrm{CO}_{3}$, DMSO, $50{ }^{\circ} \mathrm{C}, 3$ d; (b) LiCl, DMSO-H ${ }_{2} \mathrm{O}, 130{ }^{\circ} \mathrm{C}, 2 \mathrm{~h}$; (c) i. $\mathrm{Zn}$, $\mathrm{NH}_{4} \mathrm{Cl}, \mathrm{MeOH}-\mathrm{THF}, \mathrm{rt}, 2 \mathrm{~h}$; (ii) $\mathrm{Boc}_{2} \mathrm{O}, 85^{\circ} \mathrm{C}$; (iii) $\mathrm{H}_{2}, \mathrm{Pd}-\mathrm{C}, \mathrm{Boc}_{2} \mathrm{O}, \mathrm{MeOH}$, $\mathrm{rt}$; (d) $\left(\mathrm{CH}_{2} \mathrm{O}\right)_{\mathrm{n}}, \mathrm{TDA}-1, \mathrm{PhMe}, 85^{\circ} \mathrm{C}$; (e) [ $\left.\mathrm{Me}_{3} \mathrm{SO}\right] \mathrm{I}$ (3.0 equiv.), $\mathrm{NaH}$, DMSO, rt to $60^{\circ} \mathrm{C}, 3 \mathrm{~h}$; (f) $\mathrm{HCl}$, dioxane, $2 \mathrm{~h}$.

In agreement with the design strategy, we set out to synthesize an array of cycloalkyl $\mathrm{P}^{\prime}$ groups bearing carboxylate at the 1position. However, initial attempts to C-alkylate arylacetate 22 were unsuccessful, presumably because of the poor nucleophilicity of the corresponding anion due to extensive delocalization on the nitroarene system. Thus, the synthetic sequence was modified to sidestep the arylnitro precursor, which resulted in effectual delivery of substituted cycloalkyl carboxylates 42-45 (Scheme 3). Namely, nitroarene 22 was reduced to the respective aniline $\mathbf{3 2}$, which was then reacted with nitrosonium tetrafluoroborate, and the intermediate diazonium species were treated with $\mathrm{I}_{2} / \mathrm{NaI}$ to give rise to the required iodoarene precursor 33. In this instance, treatment with $\mathrm{NaH}$ and the respective dibromo electrophiles resulted in formation of substituted aryl cycloalkanes $\mathbf{3 4 - 3 7}$ in moderate to good yields. Compounds 34-37 were then subjected to $\mathrm{Cu}$-catalyzed amination conditions ${ }^{23}$ to afford anilines 38-41, which were conveniently deprotected under $\mathrm{H}_{2}(1 \mathrm{~atm})$ in the presence of Pd$\mathrm{C}$ to furnish intended intermediates $\mathbf{4 2 - 4 5}$.

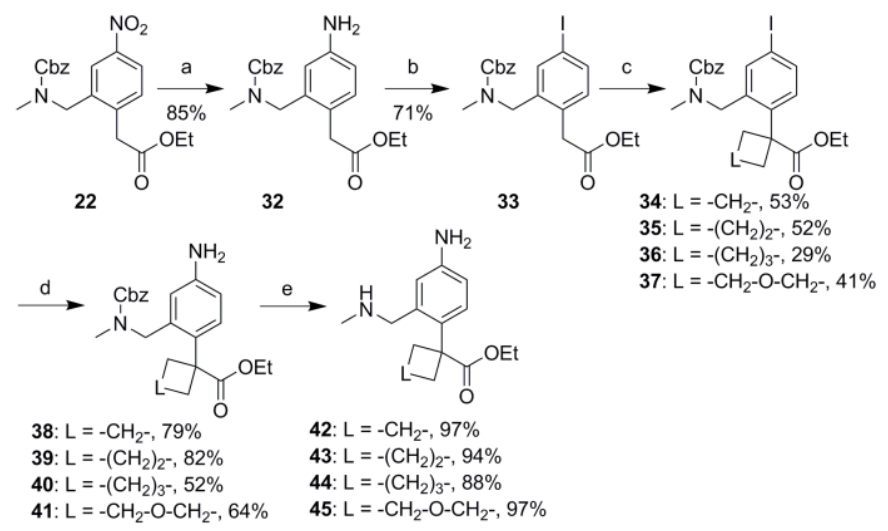

Scheme 3. Preparation of carboxyethyl cycloalkyl P1' intermediates 4245. Reagents and conditions: (a) $\mathrm{Zn}, \mathrm{NH}_{4} \mathrm{Cl}, \mathrm{MeOH}-\mathrm{THF}, \mathrm{rt}, 2 \mathrm{~h}$; (b) [NO][BF 4 ], NaI, $\mathrm{I}_{2}, \mathrm{MeCN},-40{ }^{\circ} \mathrm{C}$ to $0{ }^{\circ} \mathrm{C}, 4 \mathrm{~h}$; (c) $\mathrm{Br}$-(L)-Br, NaH, DMF, 0 ${ }^{\circ} \mathrm{C}$ to $\mathrm{rt}$; (d) acetimidamide, $\mathrm{CuI}$ ( 0.15 equiv.), ( $S$ )-Proline (0.3 equiv.), $\mathrm{Cs}_{2} \mathrm{CO}_{3}$, DMF, $100{ }^{\circ} \mathrm{C}, 2 \mathrm{~d}$; (e) $\mathrm{H}_{2}$ (1 atm), Pd-C, EtOH, rt, $1.5 \mathrm{~h}$. 
Having synthesized the necessary $\mathrm{P} 1$ ' intermediates 18, 30-31, and 42-45, we were then equipped to assemble all the target macrocyclic TF-FVIIa inhibitors. Macrocycles 10 (Figure 2) and 46 (Table 1) were accessed starting from the precursor 18 utilizing a general synthetic sequence we have disclosed earlier. $^{14,15}$ Additional macrocyclic structures $\mathbf{5 2 - 5 5}$ were constructed as outlined in Scheme 4 from previously described phenylglycine $47 .^{15}$ BOP coupling of the respective precursors afforded the required aminophenyl alcohols 48-52 in good yields. Our previously reported two-step carbamoylation protocol ${ }^{14}$ involving phosgene functionalization and subsequent slow addition to a dilute $\mathrm{MeCN}$ solution of an amine base afforded the corresponding macrocyclic carbamates, which after saponification and Boc removal yielded the desired macrocycles 53-57. $^{24}$

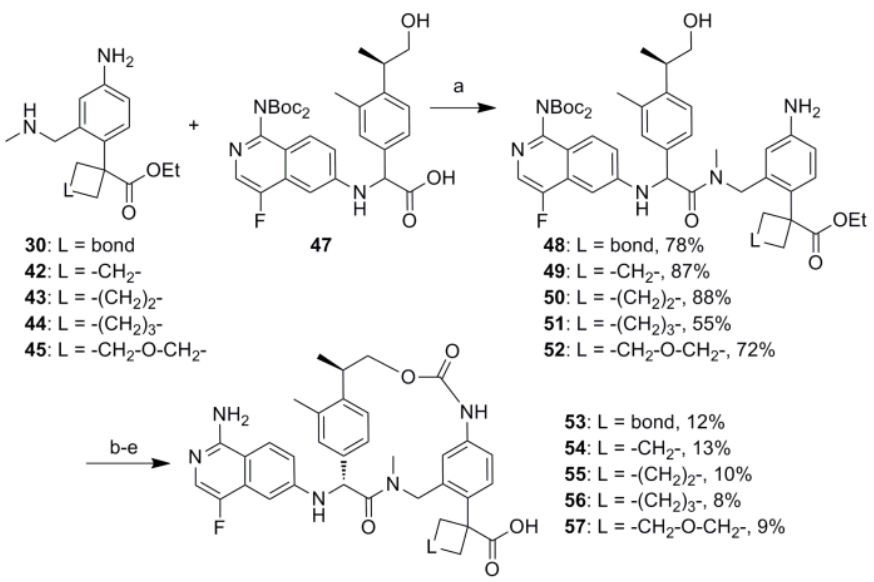

Scheme 4. Synthesis of the target macrocycles 52-55. Reagents and conditions: (a) BOP, TEA, DMF-MeCN, rt, 30 min. (b) i. $\mathrm{COCl}_{2}, \mathrm{MeCN}-$ DMPU, $0{ }^{\circ} \mathrm{C}$; ii. $\mathrm{Et}_{3} \mathrm{~N}, \mathrm{MeCN}(\sim 1 \mathrm{mM}), 70{ }^{\circ} \mathrm{C}, 3 \mathrm{~h}$; (c) chiral HPLC; (d) KOTMS, THF, $60^{\circ} \mathrm{C}, 18 \mathrm{~h}$; (e) TFA, rt, $15 \mathrm{~min}$.
To further probe charged interactions with Lys60A, an acid surrogate was introduced at the P1' moiety. Cyclopropyl-bearing macrocycle 53 was selected as a parent structure, and the tetrazole moiety was chosen as an acid bioisostere (Scheme 5). Nitrile-containing macrocycle $\mathbf{5 8}$ was prepared using a synthetic route analogous to that outlined in Scheme 4. Subsequent treatment with tributyltin azide in $\mathrm{PhMe}$ at $100{ }^{\circ} \mathrm{C}$ affected conversion of the nitrile moiety to the required tetrazole, and the sequence was concluded with Boc removal to yield macrocyclic tetrazole 59. ${ }^{24}$
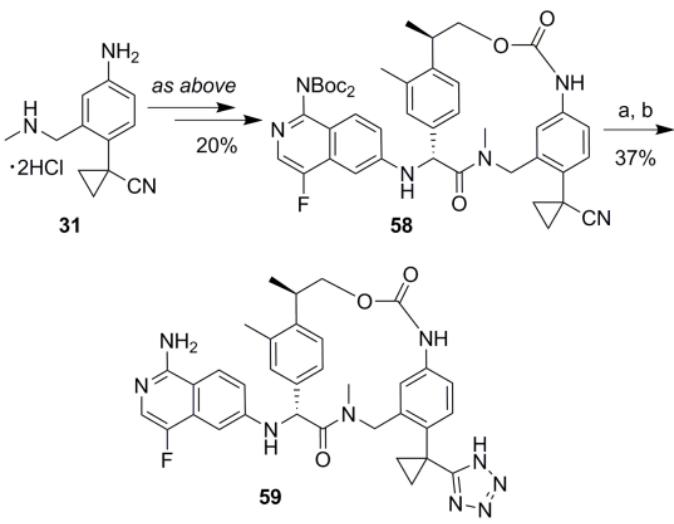

Scheme 5. Preparation of macrocycle 59. Reagents and conditions: (a) $\mathrm{Bu}_{3} \mathrm{SnN}_{3}, \mathrm{PhMe}, 105^{\circ} \mathrm{C}, 2 \mathrm{~d}$; (b) TFA, 15 min.

The series of prepared macrocycles was evaluated for TFFVIIa inhibition and compared to the corresponding parent macrocycle 46 bearing an unsubstituted cyclopropyl group at P1' region (Table 1). Gratifyingly, introduction of the carboxylic acid moiety in compound $\mathbf{5 3}$ resulted in an $\sim 30$ fold boost in inhibitory potency, and at the same time dramatically improved overall selectivity for the compound. For example, human tissue

Table 1. Structure-activity relationship of substituted cycloalkyl P1' macrocycles.
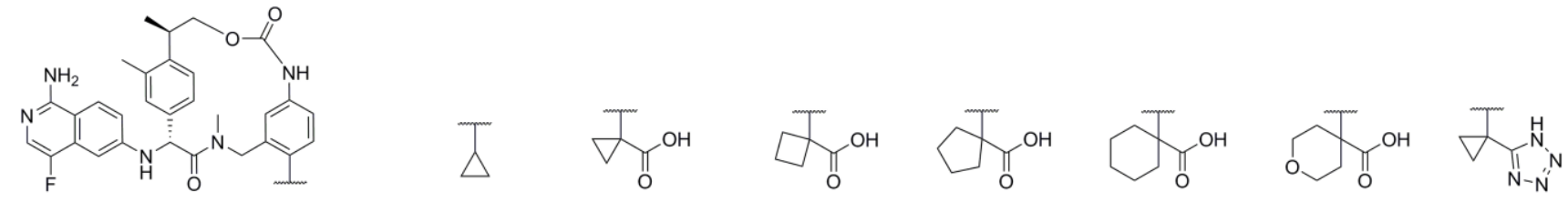

\begin{tabular}{|c|c|c|c|c|c|c|c|}
\hline Compd & 46 & 53 & 54 & 55 & 56 & 57 & 59 \\
\hline TF-FVIIa $\mathrm{K}_{\mathrm{i}} 37^{\circ} \mathrm{C}(\mathrm{nM})^{\mathrm{a}}$ & 18 & 0.55 & 0.14 & 0.22 & 0.06 & 4.4 & 0.72 \\
\hline $\mathrm{FXa} \mathrm{K}_{\mathrm{i}} 25^{\circ} \mathrm{C}(\mathrm{nM})^{\mathrm{b}}$ & 3000 & 6650 & 850 & 1800 & 900 & 1400 & 1050 \\
\hline Thrombin $\mathrm{K}_{\mathrm{i}} 25^{\circ} \mathrm{C}(\mathrm{nM})^{\mathrm{b}}$ & 18000 & $>13300$ & $>13300$ & $>13300$ & $>13300$ & $>13300$ & $>13300$ \\
\hline Trypsin $\mathrm{K}_{\mathrm{i}} 25^{\circ} \mathrm{C}(\mathrm{nM})^{\mathrm{b}}$ & $>6200$ & 2750 & 3400 & 2200 & 505 & $>6200$ & 4900 \\
\hline $\mathrm{HK}-1^{\mathrm{c}} \mathrm{K}_{\mathrm{i}} 37^{\circ} \mathrm{C}(\mathrm{nM})^{\mathrm{b}}$ & 15 & 1100 & 1150 & 1600 & 1200 & 5300 & 960 \\
\hline $\mathrm{aPC}^{\mathrm{d}} \mathrm{K}_{\mathrm{i}} 37^{\circ} \mathrm{C}(\mathrm{nM})^{\mathrm{b}}$ & 220 & 70 & 725 & 340 & 155 & 1600 & 175 \\
\hline FVII def. PT EC $2 x(\mu \mathrm{M})^{\mathrm{e}}$ & 32 & 4.7 & 7.9 & 6.6 & 18 & 11 & 10 \\
\hline Human PPB (\% free) & - & 4.4 & 3.3 & 2.8 & 1.7 & 5.8 & 1.8 \\
\hline PAMPA pH 5.5, $7.4(\mathrm{~nm} / \mathrm{s})$ &,-- & 337,117 & 209,34 & 211,40 & 805,80 & 26,21 & 119,48 \\
\hline $\mathrm{HLM} \mathrm{t}_{1 / 2}(\min )$ & 23 & $\begin{array}{c}100 \% \text { rem. } \\
@ 10 \mathrm{~min}\end{array}$ & $>120$ & - & 94 & $>120$ & 114 \\
\hline Clearance $(\mathrm{mL} / \mathrm{min} / \mathrm{kg})$ & - & - & $56(d)$ & $54(d)$ & - & - & 7 (d) \\
\hline
\end{tabular}

${ }^{\mathrm{a}}$ TF-FVIIa assays were performed with recombinant human enzyme with FX as a substrate $(\mathrm{n} \geq 2)$. ${ }^{\mathrm{b}} \mathrm{K}_{\mathrm{i}}$ 's for the indicated enzymes were determined by chromogenic substrate assays $(n=2)$. ${ }^{\mathrm{c}}$ Human tissue kallikrein-1. ${ }^{\mathrm{d}}$ Activated protein $\mathrm{C}$. ${ }^{\mathrm{e}}$ See reference 13 for a detailed description. 
kallikrein changed from being essentially equipotent for cyclopropane $46\left(\mathrm{HK}-1 \mathrm{~K}_{\mathrm{i}} / \mathrm{TF}-\mathrm{FVIIa} \mathrm{K}_{\mathrm{i}}=0.8\right)$ to being fully selective for acid analog $53\left(\mathrm{HK}-1 \mathrm{~K}_{\mathrm{i}} /\right.$ TF-FVIIa $\left.\mathrm{K}_{\mathrm{i}}=2000\right)$. Progressive expansion of the ring size in homologs 53-56 produced a gradual increase in FVIIa inhibitory activity, culminating in picomolar inhibitor $56\left(\right.$ TF-FVIIa $\left.K_{i}=60 \mathrm{pM}\right)$. It should be noted that selectivity against protease anti-targets was generally preserved in the homologous series 53-56. Of note, cyclobutyl analog 54 exhibited an optimal selectivity against aPC in the homologous 53-56 series, presumably due to differential steric requirements to bind to this anti-target. 4-THP derivative 57 was prepared to introduce a mild degree of polarity to the P1' ring system. As a result, 57 suffered $\sim 70$-fold loss in potency compared to the respective cyclohexyl analog 56, indicating that polar substituents may not be tolerated. Lastly, cyclopropyl tetrazole 59 showed an outstanding level of TF-FVIIa inhibitory potency and selectivity, illustrating that this carboxylic acid surrogate represents a competent pharmacophore for the series.

Intrigued by the substantial increase in potency associated with the introduction of cycloalkyl acid $\mathrm{P} 1$ ' groups we decided to generate X-ray crystal structures of macrocycles 54 and 56 bound to FVIIa. ${ }^{25,26}$ The structures of acids $\mathbf{5 4}$ and $\mathbf{5 6}$ are presented in Figure 4. The 4-F aminoisoquinoline P1 moiety as well as the methylphenylene P2 moiety bound in a manner consistent with $\mathrm{X}$-ray structures described previously. ${ }^{12 \mathrm{i}, 14}$ In contrast, the S1' binding pattern was quite different from the alkyl sulfone moieties. ${ }^{18 a}$ As anticipated, $\mathbf{5 4}$ carboxylate appeared to interact with the Lys60A side chain although via an intermediary water molecule. Unexpectedly, the carboxylate of $\mathbf{5 6}$ forms a water mediated interaction with Lys192 side chain. Both cyclobutyl (54) and cyclohexyl (56) groups are oriented nicely into the S1' Cys42-Cys58 pocket (3.8-5.1 $\AA$ ), forming a hydrophobic edge to edge interaction with the disulfide bridge. Overlay of cyclobutyl and cyclohexyl $\mathrm{P}^{\prime}$ ' groups is depicted in Figure 4c. As can be seen from the superimposition, the six-membered ring occupies the binding pocket more fully, which may explain the exceptional FVIIa binding affinity observed for 56. The abovementioned structural data could also explain for 4-THP analog 57 potency loss, where oxygen atom is presumably placed inside a highly hydrophobic pocket, and is thus disfavored. The interesting interactions of the carboxylic acids described above prompted us to obtain an additional crystal structure of a tetrazole acid surrogate, the des-F aminoisoquinoline analog of $\mathbf{5 9}$ (Figure 5). In this case, the tetrazole moiety is positioned in much closer proximity to the Lys60A side chain making a direct contact (2.9 $\AA$ ), presumably due to the more spatially delocalized nature of the tetrazolide anion vs the carboxylate. ${ }^{28}$ As observed for analogs 54 and 56, the cyclopropyl group efficiently interacts with the Cys42-Cys58 disulfide bridge. Overall, $\mathrm{P} 1$ ' residues in 54, 56 and 59 bind to FVIIa in a highly productive manner, providing the optimal level of ligand efficiency with almost every atom engaged in a beneficial interaction with the enzyme.

Further profiling of macrocycles 53-57 and 59 revealed that the compounds maintained good PAMPA permeability across the series, with the exception of analog 57 (Table 1). Lower PAMPA values in this case could be explained by increased polarity of the 4-THP moiety. In addition, all macrocyclic inhibitors exhibited excellent metabolic stability, and represented a substantial improvement over parent analog 46. Measured FVII deficient prothrombin time $\mathrm{EC}_{2 \mathrm{x}}$ values ${ }^{13}$ showed a stronger correlation
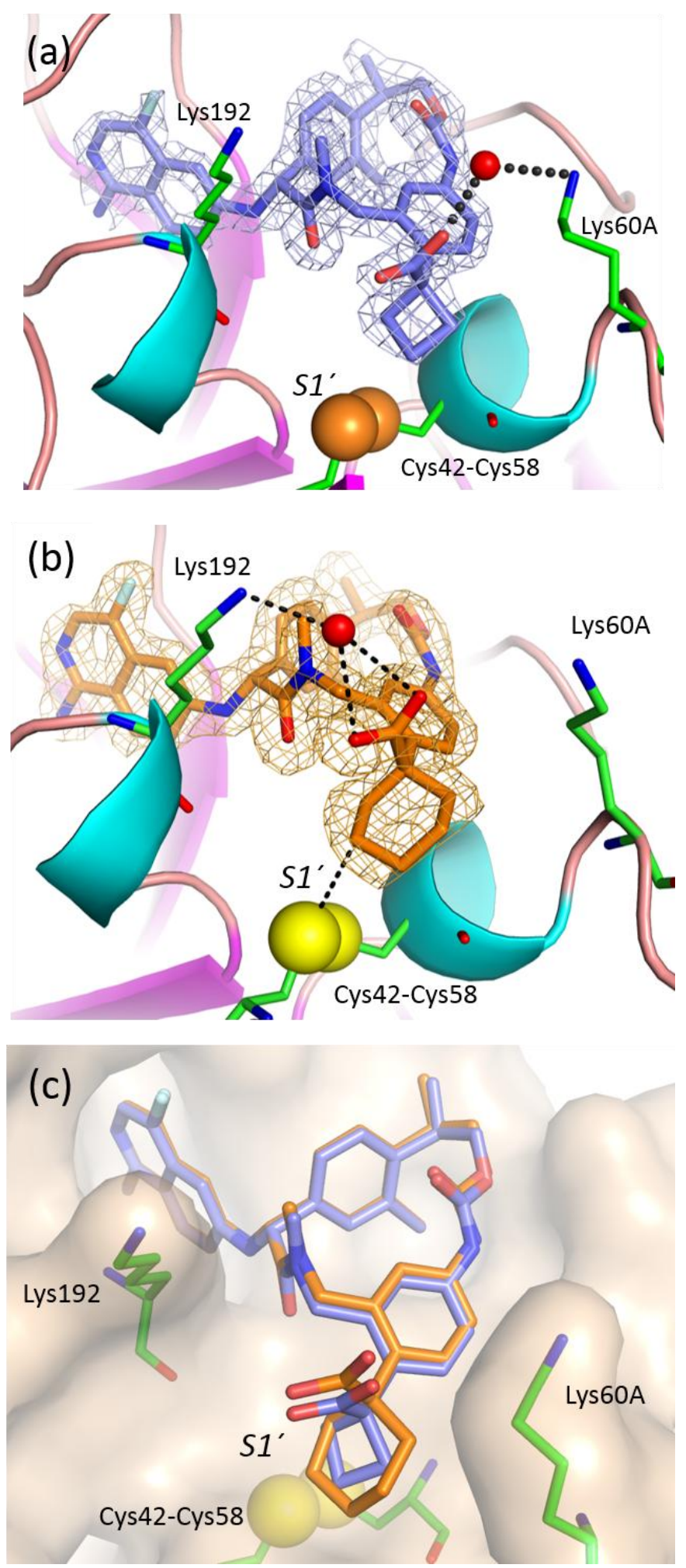

Figure 4. (a) Crystal structure of $\mathbf{5 4}$ bound to FVIIa (PDB ID: 5L2Y), solved at $1.82 \AA$. The omit Fo-Fc electron density is displayed at $5 \mathrm{rmsd}$. (b) Crystal structure of $\mathbf{5 6}$ bound to FVIIa (PDB ID: 5L2Z), solved at $1.79 \AA$ A. The omit Fo-Fc electron density is displayed at 3.5 rmsd. (c) Overlay of $\mathbf{5 4}$ with 56 at the FVIIa binding site with surface. Graphics were generated with the program PyMOL. ${ }^{27}$ 


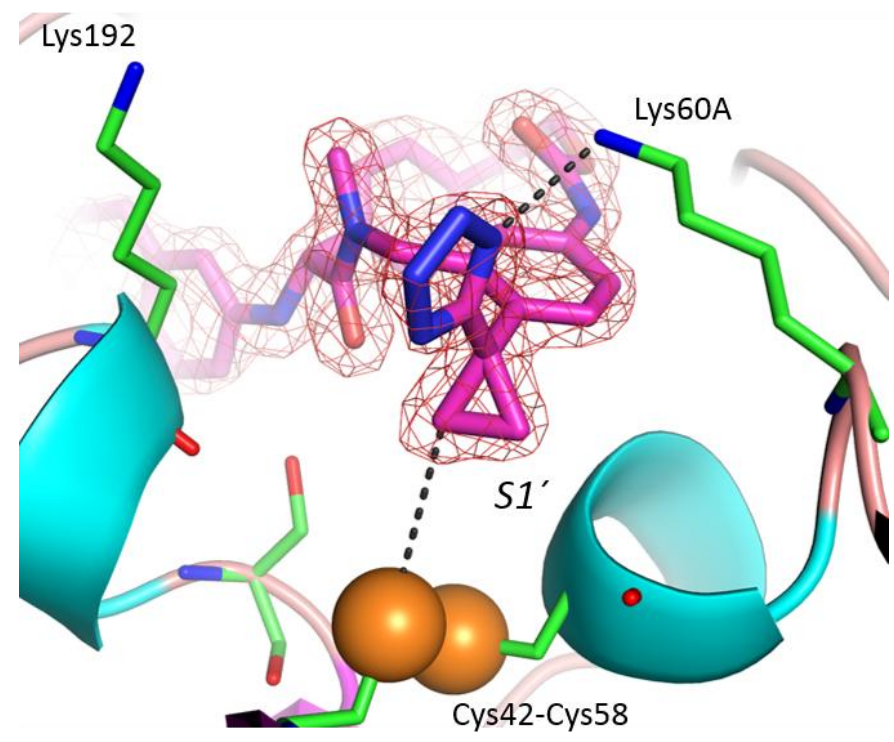

Figure 5. X-ray crystal structure of the des-F aminoisoquinoline analog of 59 complexed with FVIIa (PDB ID: 5L30), solved at $1.73 \AA$ A. The omit Fo-Fc electron density is displayed at $3.5 \mathrm{rmsd}$. Graphics were generated with the program PyMOL. ${ }^{27}$

with human plasma free fraction values rather than with the in vitro TF-FVIIa inhibition constants. For instance, the most potent analog in vitro (56; TF-FVIIa $\left.\mathrm{K}_{\mathrm{i}}=60 \mathrm{pM}\right)$ appeared to have the weakest anti-clotting activity due to a low free fraction. On the other hand, 70 -fold weaker inhibitor $\mathbf{5 7}$ showed a more robust FVII deficient prothrombin time increase due to reduced protein binding.

To further understand the effect of the novel $\mathrm{P}^{\prime}{ }^{\prime}$ groups on compounds' overall properties, two acid-containing macrocycles 54 and 55 were advanced into i.v. PK studies (Table 1). Disappointingly, both compounds showed high clearance in dog, likely due to glucuronidation of the carboxylic acid moiety. We then decided to dose tetrazolyl analog $\mathbf{5 9}$ to investigate if an acid surrogate can exert a positive effect on the overall pharmacokinetic profile. We were pleased to discover that tetrazole 59 displayed a much lower clearance of $7 \mathrm{~mL} / \mathrm{min} / \mathrm{kg}$ after i.v. administration in dogs, however low oral bioavailability $(\mathrm{F} \%=2)$ was observed. The aforementioned data suggests that tetrazole derivative $\mathbf{5 9}$ may have less propensity for glucuronidation, and could be considered an excellent starting point for further potency and ADME optimization to reach oral bioavailability.

In conclusion, we have successfully designed and synthesized macrocyclic TF-FVIIa inhibitors bearing novel 1-(1H-tetrazol-5yl)cyclopropyl and 1-carboxycycloalkyl $\mathrm{P}^{\prime}$ moieties as cyclopropyl sulfone replacements. The discovered scaffolds allowed for remarkable improvements both in FVIIa inhibitory potency (25-300 fold increase) as well as in overall protease selectivity (>1000 fold enhancement). Important highlights from the X-ray crystallography and SAR studies include: (1) carboxylic acid substituent interacts with both Lys60A and Lys192, (2) lipophilic cycloalkyl moieties are preferred, and bulkier alkyls interface more efficiently with Cys42-Cys58 motif resulting in potency boost, (3) tetrazolyl moiety performed as an acid bioisotere, allowing for similar interactions with FVIIa enzyme and yielding outstanding inhibitory potency. Ultimately, compound 59 had the optimal balance of TF-FVIIa potency, selectivity, physicochemical properties and clearance, representing an optimized and structurally diverse alternative to cyclopropyl sulfone P1'.

\section{Acknowledgements}

The authors would like to thank Dr. Rick Ewing and Dr. Donald Pinto for their valuable advice during preparation of this manuscript. Jeffrey Bozarth, Randi Brown, Tara Peterson, Mojgan Abousleiman, Frank Barbera and Yiming $\mathrm{Wu}$ are acknowledged for obtaining enzyme inhibition and clotting assay data. We also would like to thank Dr. Steven Sheriff for the help with preparation and PDB deposition of coordinates and data for FVIIa complexes with compounds 54, 56 and the des-F aminoisoquinoline analog of 59. X-ray data were collected by Rick Walter and Gina Ranieri of Shamrock Structures LLC using the IMCA beamlines, 17-BM and 17-ID, at the Advanced Photon Source. Use of the Advanced Photon Source was supported by the U.S. Department of Energy, Office of Science, Office of Basic Energy Sciences, under Contract No. DE-AC0206CH11357. Use of the IMCA-CAT beamline 17-ID at the Advanced Photon Source was supported by the companies of the Industrial Macromolecular Crystallography Association through a contract with Hauptman-Woodward Medical Research Institute.

\section{References and notes}

1. (a) Braunwald, E.; Califf, R. M.; Cannon, C. P.; Fox, K. A.; Fuster, V.; Gibler, W. B.; Harrington, R. A.; King, S. B., 3rd; Kleiman, N. S.; Theroux, P.; Topol, E. J.; Van de Werf, F.; White, H. D.; Willerson, J. T. Am. J. Med. 2000, 108, 41; (b) Cushman, M.; Tsai, A. W.; White, R. H.; Heckbert, S. R.; Rosamond, W. D.; Enright, P.; Folsom, A. R. Am. J. Med. 2004, 117, 19.

2. Ansell, J.; Hirsh, J.; Poller, L.; Bussey, H.; Jacobson, A.; Hylek, E. Chest 2004, 126, 204S.

3. De Caterina, R.; Husted, S.; Wallentin, L.; Andreotti, F.; Arnesen, H.; Bachmann, F.; Baigent, C.; Huber, K.; Jespersen, J.; Kristensen, S. D.; Lip, G. Y.; Morais, J.; Rasmussen, L. H.; Siegbahn, A.; Verheugt, F.W.; Weitz, J. I. J. Am. Coll. Cardiol. 2012, 59, 1413.

4. (a) Hauel, N. H.; Nar, H.; Priepke, H.; Ries, U.; Stassen, J. M.; Wienen, J. Med. Chem. 2002, 45, 1757; (b) Weitz, J. I.; Linkins, L. A. Expert Opin. Invest. Drugs 2007, 16, 271; (c) Haas, S.; Schellong, S. Hamostaseologie 2007, 27, 41; (d) Eriksson, B. I.; Smith, H.; Yasothan, U.; Kirkpatrick, P. Nat. Rev. Drug Discov. 2008, 7, 557; (e) Roehrig, S.; Straub, A.; Pohlmann, J.; Lampe, T.; Pernerstorfer, J. J. Med. Chem. 2005, 48, 5900; (f) Lassen, M. R.; Ageno, W.; Borris, L. C.; Lieberman, J. R.; Rosencher, N.; Bandel, T. J.; Misselwitz, F.; Turpie, A. G. G. N. Eng. J. Med. 2008, 358, 2776; (g) Straub, A.; Roehrig, S.; Hillisch, A. Curr. Top. Med. Chem. 2010, 10, 257; (h) Perzborn, E.; Roehring. S.; Straub, A.; Kubitza, D.; Misselwitz, F. Nat. Rev. Drug Discov. 2011, 10, 61; (i) Pinto, D.; Orwat, M.; Koch, S.; Rossi, K.; Alexander, R.; Smallwood, A.; Wong, P.; Rendina, A.; Luettgen, J. M.; Knabb, R. M.; Xin, B.; Wexler, R. R.; Lam, P. J. Med. Chem. 2007, 50, 5339; (j) He, K.; Luettgen, J. M.; Zhang, D.; He, B.; Grace, J. E. Jr.; Xin, B.; Pinto, D. J. P.; Wong, P. C.; Knabb, R. M.; Lam, P. Y. S.; Wexler, R. R.; Grossman, S. J. Eur. J. Drug Metab. Pharm. 2011, 36, 129; (k) Pinto, D. J. P.; Smallheer, J. M.; Cheney, D. L.; Knabb, R., M.; Wexler, R. R. J. Med. Chem. 2010, 53, 6243; (1) Furugohri, T.; Isobe, K., Honda, Y., KamisatoMatsumoto, C.; Sugiyama, N.; Nagahara, T.; Morishima, Y.; Shibano, T. J. Thromb. Haemost. 2008, 6, 1542. (m) Bounameaux, H.; Camm A. J.; Drugs 2014, 74, 1209.

5. Bauer, K. A. Hematology Am. Soc. Hematol. Educ. Program 2013, 2013, 464.

6. Priestley, E. S. Drug Discov. Today 2014, 19, 1440

7. (a) Steffel, J.; Lüscher, T. F.; Tanner, F. C. Circulation 2006, 113, 722; (b) Petrillo, G.; Cirillo, P.; D’Ascoli, G. L.; Maresca, F.; Ziviello, F.; Chiariello, M. Curr. Cardiol. Rev. 2010, 6, 325;

8. (a) Steffel, J.; Lüscher, T. F.; Tanner, F. C. Circulation 2006, 113, 722; (b) Petrillo, G.; Cirillo, P.; D’Ascoli, G. L.; Maresca, F.; Ziviello, F.; Chiariello, M. Curr. Cardiol. Rev. 2010, 6, 325; (a) Himber, J.; Kirchhofer, D.; Riederer, M.; Tschopp, T.; Steiner, B.; Roux, S. Thromb. Haemost. 1997, 78, 1142; (b) Himber, J.; Refino, C. J.; Burcklen, L.; Roux, S.; Kirchhofer, D. Thromb. Haemost. 2001, 85, 475; (c) Golino, P.; Ragni, M.; Cirillo, P.; D'Andrea, D.; Scognamiglio, A.; Ravera, A.; Buono, C.; Ezban, 
M.; Corcione, N.; Vigorito, F. Circul. Res. 1998, 82, 39; (d) Szalony, J. A.; Suleymanov, O. D.; Salyers, A. K.; Panzer-Knodle, S. G.; Blom, J. D.; LaChance, R. M.; Case, B. L.; Parlow, J. J.; South, M. S.; Wood, R. S.; Nicholson, N. S. Thromb. Res. 2003 , 112, 167; (e) Suleymanov, O. D.; Szalony, J. A.; Salyers, A. K.; LaChance, R. M.; Parlow, J. J.; South, M. S.; Wood, R. S.; Nicholson, N. S. J. Pharmacol. Exp. Ther. 2003, 306, 1115. (f) Salyers, A. K.; Szalony, J. A.; Suleymanov, O. D.; Parlow, J. J.; Wood, R. S.; South, M. S.; Nicholson, N. S. Pharmacology 2004, 70, 100; (g) Olivero, A. G.; Eigenbrot, C.; Goldsmith, R.; Robarge, K.; Artis, D. R.; Flygare, J.; Rawson, T.; Sutherlin, D. P.; Kadkhodayan, S.; Beresini, M.; Elliott, L. O.; DeGuzman, G. G.; Banner, D. W.; Ultsch, M.; Marzec, U.; Hanson, S. R.; Refino, C.; Bunting, S.; Kirchhofer, D. J. Biol. Chem. 2005, 280, 9160; (h) Zbinden, K. G.; Banner, D. W.; Hilpert, K.; Himber, J.; Lavé, T.; Riederer, M. A.; Stahl, M.; Tschopp, T. B.; Obst-Sander, U. Biorg. Med. Chem. 2006, 14, 5357; (i) Young, W. B.; Mordenti, J.; Torkelson, S.; Shrader, W. D.; Kolesnikov, A.; Rai, R.; Liu, L.; Hu, H.; Leahy, E. M.; Green, M. J.; Sprengeler, P. A.; Katz, B. A.; Yu, C.; Janc, J. W.; Elrod, K. C.; Marzec, U. M.; Hanson, S. R., Bioorg. Med. Chem. Lett. 2006, 16, 2037; (j) Arnold, C. S.; Parker, C.; Upshaw, R.; Prydz, H.; Chand, P.; Kotian, P.; Bantia, S.; Babu, Y. S. Thromb. Res. 2006, 117, 343; (k) Wong, P. C.; Luettgen, J. M.; Rendina, A. R.; Kettner, C. A.; Xin, B.; Knabb, R. M.; Wexler, R.; Priestley, E. S. Thromb. Haemost. 2010, 104, 261; (1) Nagakura, T.; Tabata, K.; Kira, K.; Hirota, S.; Clark, R.; Matsuura, F.; Hiyoshi, H., Thromb. Res. 2013, 132, 271.

9. (a) Liu, Y.; Jiang, P.; Capkova, K.; Xue, D.; Ye, L.; Sinha, S. C.; Mackman, N.; Janda, K. D.; Liu C. Cancer Res. 2011, 71, 6492; (b) Sampson, M. T.; Kakkar, A. K. Biochem. Soc. Trans. 2002, 30 , 201. (c) Meuller, B.M.; Ruf, W. J. Clin. Invest. 1998, 101, 1372.

10. (a) Taylor, F. B.; Chang, A. C.; Peer, G.; Li, A.; Ezban, M.; Hedner, U. Blood 1998, 91, 1609; (b) Camerer, E.; Huang, W.; Coughlin, S. R. Proc. Natl. Acad. Sci. 2000, 97, 5255.

11. Quan, M. L.; Glunz, P. W.; Smallheer, J. M. Advances in Anticoagulants (Book Chapter), 2016, accepted for publication.

12. (a) Schechter, I.; Berger, A., Biochem. Biophys. Res. Commun 1967, 27, 157; (b) Mahesh, S. A.; Gabrail, N. Y.; Gandhi, J. G.; Khorana, A. A.; Manges, R.; Shah, S.; Thomas, G. W.; Hamdy, A. M.; Stevens-Brogan, M.; Zhou, C. J. Clin. Oncol. 2013, 31, e15014; (c) Arnold, C. S.; Parker, C.; Upshaw, R.; Prydz, H.; Chand, P.; Kotian, P.; Bantia, S.; Babu, Y. S. Thromb. Res. 2006 117, 343-349; (d) Kotian, P. L.; Krishnan, R.; Rowland, S.; ElKattan, Y.; Saini, S. K.; Upshaw, R.; Bantia, S.; Arnold, S.; Babu, Y. S.; Chand, P. Bioorg. Med. Chem. 2009, 17, 3934; (e) Glunz, P. W.; Cheng, X.; Cheney, D. L.; Weigelt, C. A.; Wei, A.; Luettgen, J. M.; Wong, P. C.; Wexler, R. R.; Priestley, E. S. Bioorg. Med. Chem. Lett. 2015, 25, 2169-2173; (f) Nagakura, T.; Tabata, K.; Kira, K.; Hirota, S.; Clark, R.; Matsuura, F.; Hiyoshi, H. Thromb. Res. 2013, 132, 271; (g) Hu, H.; Kolesnikov, A.; Riggs, J. R.; Wesson, K. E.; Stephens, R.; Leahy, E. M.; Shrader, W. D.; Sprengeler, P. A.; Green, M. J.; Sanford, E.; Nguyen, M.; Gjerstad, E.; Cabuslay, R.; Young, W. B. Bioorg. Med. Chem. Lett. 2006, 16, 4567; (h) Miura, M.; Seki, N.; Koike, T.; Ishihara, T.; Niimi, T.; Hirayama, F.; Shigenaga, T.; Sakai-Moritani, Y.; Tagawa, A.; Kawasaki, T.; Sakamoto, S.; Okada, M.; Ohta, M.; Tsukamoto, S. Bioorg. Med. Chem. 2007, 15, 160; (i) Cheney, D. L.; Bozarth, J. M.; Metzler, W. J.; Morin, P. E.; Mueller, L.; Newitt, J. A.; Nirschl, A. H.; Rendina, A. R.; Tamura, J. K.; Wei, A.; Wen, X.; Wurtz, N. R.; Seiffert, D. A.; Wexler, R. R.; Priestley, E. S. J. Med. Chem. 2015, 58, 2799; (j) Priestley, E. S.; Cheney, D. L.; DeLucca, I.; Wei, A.; Luettgen, J. M.; Rendina, A. R.; Wong, P. C.; Wexler, R. R. J. Med. Chem. 2015, 58, 6225.

13. Wong, P. C.; Luettgen, J. M.; Rendina, A. R.; Kettner, C. A.; Xian, B.; Knabb, R. M.; Wexler, R. R.; Priestley, E. S. Thromb. Haemostasis 2010, 104, 261

14. Glunz, P. W.; Mueller, L.; Cheney, D. L.; Ladziata, V.; Zou, Y.; Wurtz, N. R.; Wei, A.; Wong, P. C.; Wexler, R. R.; Priestley, E. S. J. Med. Chem. 2016, 59, 4007 .

15. Zhang, X.; Glunz, P. W.; Johnson, J. A.; Jiang, W.; Jacutin-Porte, S.; Ladziata, V.; Zou, Y.; Phillips, M. S.; Wurtz, N. R.; Parkhurst, B.; Rendina, A. R.; Harper, T. M.; Cheney, D. L.; Luettgen, J. M.; Wong, P. C.; Seiffert, D.; Wexler, R. R.; E. Priestley, E. S. J. Med. Chem. 2016, 59, 7125

16. McNaney, C. A.; Dexler, D. M.; Hnatyshyn, S. Y.; Zvyaga, T. A.; Knipe, J. O.; Belcastro, J. V.; Sanders, M. ASSAY Drug Dev. Techn. 2008, 6, 121.

17. van Breemen, R. B.; Li, Y. Expert Opin. Drug. Metab. Toxicol. 2005, 1,175 .
18. (a) Zhang, X.; Jiang, W.; Jacutin-Porte, S.; Glunz, W. P.; Zou, Y.; Cheng, X.; Nirschl, H. A.; Wurtz, R. N.; Luettgen, M. J.; Rendina, R. A.; Luo, G.; Harper, M. T.; Wei, A.; Anumula, R.; Cheney, L. D.; Knabb, M. R.; Wong, C. P.; Wexler, R. R.; Priestley, E. S. ACS Med. Chem. Lett. 2014, 5, 188; (b) Glunz, P. W.; Zhang, X.; Zou, Y.; Nirschl, A. H.; Cheng, X.; Weigelt, C. A.; Cheney, D. L.; Wei, A.; Wen, X.; Bozarth, J. M.; Normandin, D. E.; Hartl, K. S.; Rendina, A. R.; Barbera, F. A.; Luettgen, J. M.; Brown, R. L.; Peterson, T.; Zhang, G.; Wong, P. C.; Harpel, M.; Shen, L.; M., K. R.; Wexler, R. R.; Priestley, E. S. Bioorg. Med. Chem. Lett. 2013, 23, 5244 .

19. Wallace, D. J.; Chen, C-Y. Tetrahedron Lett. 2002, 43, 6987.

20. Ma, D.; Cai, Q. Acc. Chem. Res. 2008, 41, 1450.

21. (a) Krapcho, A. P.; Weimaster, J. F.; Eldridge, J. M.; Jahngen, E. G. E., Jr.; Lovey, A. J.; Stephens, W. P. J. Org. Chem. 1978, 43, 138; (b) Krapcho, A. P.; Ciganek, E. Org. React. 2013, 81, 1.

22. (a) Corey, E. J.; Chaykovsky, M. J. Am. Chem. Soc. 1962, 84 , 867; (b) Corey, E. J.; Chaykovsky, M. J. Am. Chem. Soc. 1962, 84, 3782; (c) Corey, E. J.; Chaykovsky, M. J. Am. Chem. Soc. 1965, 87,1353

23. Gao, X.; Fu, H.; Qiao, R.; Jiang, Y.; Zhao, Y. J. Org. Chem. 2008, 73,6864 .

24. 53: MS (ESI) $m / z: 612.2[\mathrm{M}+1]^{+} ;{ }^{1} \mathrm{H}$ NMR (400 MHz, $\left.\mathrm{CD}_{3} \mathrm{OD}\right) \delta$ ppm 8.09 (dd, $J=9.3,2.0 \mathrm{~Hz}, 1 \mathrm{H}), 7.65$ (dd, $J=8.0,1.8 \mathrm{~Hz}, 1 \mathrm{H})$, $7.45(\mathrm{~d}, J=8.0 \mathrm{~Hz}, 1 \mathrm{H}), 7.42(\mathrm{~d}, J=5.0 \mathrm{~Hz}, 1 \mathrm{H}), 7.28(\mathrm{dd}, \mathrm{J}=9.3$, $2.3 \mathrm{~Hz}, 1 \mathrm{H}), 7.21(\mathrm{~s}, 1 \mathrm{H}), 7.16(\mathrm{~d}, J=8.3 \mathrm{~Hz}, 1 \mathrm{H}), 6.97(\mathrm{~s}, 1 \mathrm{H})$, $6.67(\mathrm{dd}, J=8.0,2.3 \mathrm{~Hz}, 1 \mathrm{H}), 5.97(\mathrm{~d}, J=2.0 \mathrm{~Hz}, 1 \mathrm{H}), 5.77(\mathrm{~s}, 1 \mathrm{H})$, $5.54(\mathrm{~d}, J=16.8 \mathrm{~Hz}, 1 \mathrm{H}), 4.64(\mathrm{t}, J=10.9 \mathrm{~Hz}, 1 \mathrm{H}), 3.89-4.00(\mathrm{~m}$, 2H), 3.43-3.53 (m, 1H), 3.28 (s, 3H), 2.32 (s, 3H), 1.64 (br. s., 2H), 1.31 (d, $J=7.0 \mathrm{~Hz}, 3 \mathrm{H}$, ), 1.20 (br. s., $2 \mathrm{H}$ ). 54: MS (ESI) $\mathrm{m} / \mathrm{z}$ : $626.3[\mathrm{M}+1]^{+} ;{ }^{1} \mathrm{H}$ NMR $\left(400 \mathrm{MHz}, \mathrm{CD}_{3} \mathrm{OD}\right) \delta \mathrm{ppm} 8.09(\mathrm{dd}$, $J=9.2,1.9 \mathrm{~Hz}, 1 \mathrm{H}), 7.62(\mathrm{dd}, J=7.9,1.63 \mathrm{~Hz}, 1 \mathrm{H}), 7.40-7.47(\mathrm{~m}$, 2H), $7.28(\mathrm{dd}, J=9.3,2.5 \mathrm{~Hz}, 1 \mathrm{H}), 7.22$ (d, $J=1.5 \mathrm{~Hz}, 1 \mathrm{H}), 7.13$ (d, $J=8.3 \mathrm{~Hz}, 1 \mathrm{H}), 6.97(\mathrm{~s}, 1 \mathrm{H}), 6.73(\mathrm{dd}, J=8.2,2.1 \mathrm{~Hz}, 1 \mathrm{H}), 5.93(\mathrm{~d}$, $J=2.01 \mathrm{~Hz}, 1 \mathrm{H}), 5.70-5.79(\mathrm{~m}, 1 \mathrm{H}), 5.36(\mathrm{~d}, J=16.6 \mathrm{~Hz}, 1 \mathrm{H}), 4.61$ (t, $J=10.9 \mathrm{~Hz}, 1 \mathrm{H}), 3.97$ (dd, $J=10.8,4.3 \mathrm{~Hz}, 1 \mathrm{H}), 3.81$ (d, $J=16.6$ $\mathrm{Hz}, 1 \mathrm{H}), 3.42-3.55(\mathrm{~m}, 1 \mathrm{H}), 3.20(\mathrm{~s}, 2 \mathrm{H}), 2.72-2.86(\mathrm{~m}, 2 \mathrm{H}), 2.46-$ $2.61(\mathrm{~m}, 2 \mathrm{H}), 2.10-2.24(\mathrm{~m}, 1 \mathrm{H}), 2.03(\mathrm{~s}, 3 \mathrm{H}), 1.78-1.91(\mathrm{~m}, 1 \mathrm{H})$, $1.31(\mathrm{~d}, J=7.0 \mathrm{~Hz}, 3 \mathrm{H})$. 55: MS (ESI) $\mathrm{m} / \mathrm{z}: 640.3[\mathrm{M}+1]^{+} ;{ }^{1} \mathrm{H}$ NMR $\left(400 \mathrm{MHz}, \mathrm{CD}_{3} \mathrm{OD}\right) \delta \mathrm{ppm} 8.86(\mathrm{~s}, 1 \mathrm{H}), 8.08$ (dd, $J=9.3,1.8$ $\mathrm{Hz}, 1 \mathrm{H}), 7.62(\mathrm{dd}, J=8.0,1.5 \mathrm{~Hz}, 1 \mathrm{H}), 7.38-7.47(\mathrm{~m}, 2 \mathrm{H}), 7.25-$ $7.34(\mathrm{~m}, 2 \mathrm{H}), 7.22$ (s, 1H), 6.96 (br. s., $1 \mathrm{H}), 6.72$ (dd, $J=8.3,2.3$ $\mathrm{Hz}, 1 \mathrm{H}), 6.01$ (d, J=2.0 Hz, 1H), 5.75 (s, 1H), 5.46 (d, $J=16.3 \mathrm{~Hz}$, $1 \mathrm{H}), 4.59$ (t, $J=10.9 \mathrm{~Hz}, 1 \mathrm{H}), 3.97$ (dd, $J=10.8,4.3 \mathrm{~Hz}, 1 \mathrm{H}), 3.88$ $(\mathrm{d}, J=16.3 \mathrm{~Hz}, 1 \mathrm{H}), 3.42-3.55(\mathrm{~m}, 1 \mathrm{H}), 3.20(\mathrm{~s}, 3 \mathrm{H}), 2.59(\mathrm{dt}$, $J=12.7,6.3 \mathrm{~Hz}, 1 \mathrm{H}), 2.43-2.53(\mathrm{~m}, 1 \mathrm{H}), 2.33$ (s, 3H), 1.90-2.09 $(\mathrm{m}, 2 \mathrm{H}), 1.65-1.84(\mathrm{~m}, 4 \mathrm{H}), 1.31(\mathrm{~d}, J=7.0 \mathrm{~Hz}, 3 \mathrm{H}) . \mathbf{5 6}$ : MS (ESI) $m / z: 654.3[\mathrm{M}+1]^{+} ;{ }^{1} \mathrm{H}$ NMR $\left(400 \mathrm{MHz}, \mathrm{CD}_{3} \mathrm{OD}\right) \delta \mathrm{ppm} 8.10(\mathrm{dd}$, $J=9.2,1.9 \mathrm{~Hz}, 1 \mathrm{H}), 7.60(\mathrm{dd}, J=7.8,1.8 \mathrm{~Hz}, 1 \mathrm{H}), 7.36-7.47(\mathrm{~m}$, $3 \mathrm{H}), 7.26-7.32(\mathrm{~m}, 1 \mathrm{H}), 7.21(\mathrm{~s}, 1 \mathrm{H}), 6.97(1 \mathrm{H}, \mathrm{s}), 6.75(\mathrm{dd}$, $J=8.5,2.3 \mathrm{~Hz}, 1 \mathrm{H}), 6.04(1 \mathrm{H}, \mathrm{s}), 5.74(\mathrm{~s}, 1 \mathrm{H}), 5.51(\mathrm{~d}, J=16.3 \mathrm{~Hz}$, $1 \mathrm{H}), 4.57(\mathrm{t}, J=10.9 \mathrm{~Hz}, 1 \mathrm{H}), 3.93-4.03(\mathrm{~m}, 2 \mathrm{H}), 3.44-3.54(\mathrm{~m}$, 1H), $3.18(\mathrm{~s}, 3 \mathrm{H}), 2.41(\mathrm{~d}, J=15.3 \mathrm{~Hz}, 1 \mathrm{H}), 2.35(\mathrm{~s}, 3 \mathrm{H}), 2.30(\mathrm{~d}$, $J=13.8 \mathrm{~Hz}, 1 \mathrm{H}), 1.75-1.88(\mathrm{~m}, 2 \mathrm{H}), 1.55-1.74(\mathrm{~m}, 5 \mathrm{H}), 1.34-1.42$ $(\mathrm{m}, 1 \mathrm{H}), 1.32$ (d, $J=7.0 \mathrm{~Hz}, 3 \mathrm{H})$ 57: MS (ESI) $\mathrm{m} / z: 656.2[\mathrm{M}+1]^{+}$; ${ }^{1} \mathrm{H}$ NMR (400 MHz, CD $\left.{ }_{3} \mathrm{OD}\right) \delta \mathrm{ppm} 8.92(\mathrm{~s}, 1 \mathrm{H}), 8.10$ (dd, $J=9.3$, $1.8 \mathrm{~Hz}, 1 \mathrm{H}), 7.61(\mathrm{~d}, J=7.8 \mathrm{~Hz}, 1 \mathrm{H}), 7.40-7.48(\mathrm{~m}, 2 \mathrm{H}), 7.37(\mathrm{~d}$, $J=8.5 \mathrm{~Hz}, 1 \mathrm{H}), 7.29$ (dd, $J=9.3,2.3 \mathrm{~Hz}, 1 \mathrm{H}), 7.19(1 \mathrm{H}, \mathrm{s}), 6.96(1$ H, br. s.), 6.77 (dd, $J=8.4,2.1 \mathrm{~Hz}, 1 \mathrm{H}), 6.09$ (s, 1H), 5.75 (s, 1H), $5.50(\mathrm{~d}, J=16.3 \mathrm{~Hz}, 1 \mathrm{H}), 4.58(\mathrm{t}, J=10.9 \mathrm{~Hz}, 1 \mathrm{H}), 3.93-4.03(\mathrm{~m}$, $2 \mathrm{H}), 3.71-3.91(\mathrm{~m}, 3 \mathrm{H}), 3.42-3.54(\mathrm{~m}, 1 \mathrm{H}), 3.20(\mathrm{~s}, 3 \mathrm{H}), 2.46(\mathrm{~d}$, $J=15.1 \mathrm{~Hz}, 1 \mathrm{H}), 2.34(\mathrm{~s}, 3 \mathrm{H}), 2.03-2.15(\mathrm{~m}, 1 \mathrm{H}), 1.89-2.01(\mathrm{~m}$, 1H), 1.32 (d, J=7.0 Hz, 3H). 59: MS (ESI) $m / z: 636.2[\mathrm{M}+1]^{+} ;{ }^{1} \mathrm{H}$ NMR (400 MHz, CD 3 OD) $\delta$ ppm $9.03(\mathrm{~s}, 1 \mathrm{H}), 8.09$ (dd, $J=9.4$, $1.77 \mathrm{~Hz}, 1 \mathrm{H}), 7.65$ (dd, $J=8.1,1.8 \mathrm{~Hz}, 1 \mathrm{H}), 7.47$ (d, $J=8.1 \mathrm{~Hz}$, $1 \mathrm{H}), 7.43$ (d, J=4.8 Hz, 1H), 7.36 (d, J=8.1 Hz, 1H), 7.29 (dd, $J=9.4,2.3 \mathrm{~Hz}, 1 \mathrm{H}), 7.14(\mathrm{~s}, 1 \mathrm{H}), 6.96(\mathrm{~s}, 1 \mathrm{H}), 6.77(\mathrm{dd}, J=8.1,2.0$ $\mathrm{Hz}, 1 \mathrm{H}), 6.09-6.15(\mathrm{~m}, 1 \mathrm{H}), 5.76(\mathrm{~s}, 1 \mathrm{H}), 5.27(\mathrm{~d}, J=16.9 \mathrm{~Hz}, 1 \mathrm{H})$, 4.67 (t, $J=11.1 \mathrm{~Hz}, 1 \mathrm{H}), 3.97$ (dd, $J=10.7,4.4 \mathrm{~Hz}, 1 \mathrm{H}), 3.81$ (d, $J=16.7 \mathrm{~Hz}, 1 \mathrm{H}), 3.44-3.56(\mathrm{~m}, 1 \mathrm{H}), 2.31$ (s, 3H), 1.65-1.84 (m, $2 \mathrm{H}), 1.48-1.61(\mathrm{~m}, 2 \mathrm{H}), 1.32(\mathrm{~d}, J=7.1 \mathrm{~Hz}, 3 \mathrm{H})$

25. Relative atomic coordinates for the crystallographic structures of $\mathbf{5 4}, \mathbf{5 6}$, and the des-F aminoisoquinoline analog of $\mathbf{5 9}$ complexed with factor VIIa have been deposited in the PDB; their deposition numbers are 5L2Y, 5L2Z, 5L30, respectively.

26. For procedures for crystallization, data collection, and structure refinement, please see ref. $12 \mathrm{j}$

27. The PyMOL Molecular Graphics System, Version 1.7 Schrödinger, LLC 
28. (a) Carini, D. J.; Christ, D. D.; Duncia, J. V.; Pierce, M. E. Pharm. Biotechnol. 1998, 11, 29. (b) Naylor, E. M.; Chakravarty, P. K.; Costello, C. A.; Chang, R. S.; Chen, T.-B.; Faust, K. A.; Lotti, V. J.; Kivlighn, S. D.; Zingaro, G. J.; Siegl, P. K. S.; Wong, P. C.; Carini, D. J.; Wexler, R. R.; Patchett, A. A.; Greenlee, W. J. Bioorg. Med. Chem. Lett. 1993, 3, 69. 


\section{Graphical Abstract}

To create your abstract, type over the instructions in the template box below.

Fonts or abstract dimensions should not be changed or altered.

\section{Synthesis and P1' SAR Exploration of Potent Macrocyclic Tissue Factor-Factor VIIa \\ Inhibitors}

Vladimir (Uladzimir) Ladziata, ${ }^{*}$ Peter W. Glunz, Yan Zou, ${ }^{\dagger}$ Xiaojun Zhang, Wen Jiang, Swanee Jacutin-Porte, Daniel L. Cheney, Anzhi Wei, Joseph M. Luettgen, Timothy M. Harper, Pancras C. Wong, Dietmar Seiffert, Ruth R. Wexler, E. Scott Priestley

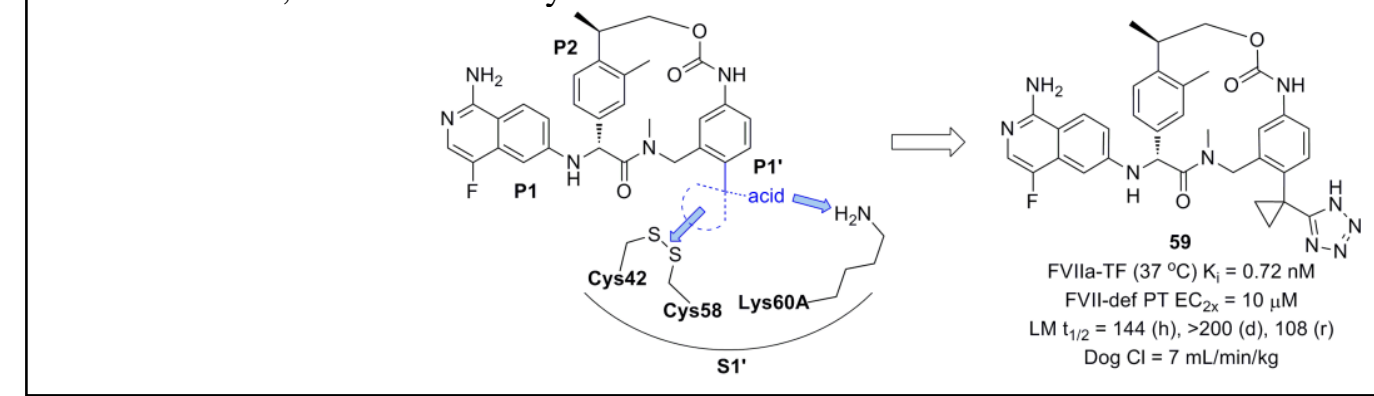

